\title{
IMPLEMENTASI KEARIFAN LOKAL DALAM STRATEGI PENGEMBANGAN WISATA PANTAI SENDANG BIRU UNTUK PELESTARIAN PULAU SEMPU
}

\author{
Fenny Widiana ${ }^{1}$, Respati Wikantiyoso ${ }^{2}$ \\ ${ }^{1}$ Mahasiswa Magister Arsitektur Lingkungan Binaan Universitas Brawijaya \\ ${ }^{2}$ Guru Besar Teknik Arsitektur Universitas Merdeka Malang \\ fenny.widiana@gmail.com \\ 085234072322
}

\begin{abstract}
Abstrak
Kata kunci: kearifan lokal, wisata pantai, pulau sempu,

Indonesia merupakan Negara kepulauan terbesar di dunia yang memiliki ribuan pulau dari Sabang sampai Merauke, dimana setiap pulaunya memiliki keunikan tersendiri. Salah satu pantai di kabupaten Malang adalah pantai Sendang Biru. Pantai Sendang Biru memiliki potensi sumber daya perikanan yang besar di jawa Timur. Daya tarik berupa tempat pelelangan ikan dan pulau Sempu yang berada di sebrang pantai yang ditetapkan sebagai cagar alam melalui Surat Keputusan Gubernur Jenderal Hindia Belanda pada tahun 1928. Permasalahan pada pulau Sempu adalah adanya wisata illegal sehingga membuat sebagian wilayahnya menjadi rusak dan sebagian kawasan di pulau Sempu akan diubah menjadi Taman Wisata Alam (TWA). Metode kajian ini menggunakan metode deskriptif untuk menidentifikasi kearifan lokal dan menganalisa sehingga mendapatkan strategi pengembangan kawasan wisata Pantai Sendang Biru. Ditemukan bahwa kearifan lokal dapat dijadikan dasar pengembangan wisata kuliner dan atraksi kehidupan nelayan pada Pantai Sendang biru. Dengan pengembangan kualitas wisata di Pantai Sendang Biru diharapkan dapat melestarikan Pulau Sempu.

Keywords: local wisdom, beach tourism, Sempu island

Abstract

Indonesia is the largest archipelago country in the world that has thousands of islands from Sabang to Merauke, where each island has its own uniqueness. One of the beaches in Malang Regency is Sendang Biru beach. Sendang Biru Beach has great fishery resource potential in East Java. The attractiveness of fish auction sites and Sempu island located along the coast which is designated as a nature reserve through the Decree of the Governor General of Dutch East Indies in 1928. Problems on the island of Sempu is the illegal tourism that makes some of its territories become damaged and some areas on the island Sempu will be transformed into a Nature Tourist Park. This study method uses the descriptive method to identify local wisdom and analyze so get strategy development of tourist area of Sendang Biru Beach. Found that local wisdom can be used as the basis for the development of culinary tourism and attractions of fisherman life on the blue Sendang Beach. With the development of the quality of tourism in Pantai Sendang Biru is expected to preserve Sempu Island.
\end{abstract}




\section{Pendahuluan}

Indonesia merupakan Negara kepulauan terbesar di dunia yang memiliki ribuan pulau dari Sabang sampai Merauke, dimana setiap pulaunya memiliki keunikan tersendiri. Malang merupakan salah satu kota/kabupaten di Pulau Jawa bagian timur yang memiliki pantai yang berbatasan langsung dengan Samudra Hindia. Pantai pada bagian selatan kabupaten Malang biasa disebut dengan pantai laut selatan. Terdapat sekitar 45 pantai eksotik yang dapat menjadi objek tujuan wisata karena keindahan alamnya.

Hamparan laut yang luas, dataran, hempasan angin, udara, beragam jenis tanaman dan pepohonan serta beragam jenis satwa merupakan beberapa komponen yang dimiliki daerah beriklim tropis seperti Indonesia, khususnya kota Malang. Komponen-komponen tersebut bergabung membentuk kondisi seperti siang, malam, cerah, mendung, panas, dingin, teduh, terik dan sebagainya. Kondisi tersebut adalah bahasa alam untuk mengekspresikan keseimbangan ekosistem (Antaryama, 2009).

Masyarakat di masa lalu memahami dengan baik bahasa-bahasa alam. Bahasa-bahasa alam dikumpulkan dengan pengalaman coba-coba (trial and error) dalam jangka waktu yang lama menjadi sebah sistem pengetahuan yang digunakan untuk mengelola alam. Menurut Sistem pengetahuan tersebut menjadi khas pada suatu tempat dan berorientasi pada bahasa alam sering disebut dengan kearifan lokal (local wisdom) (Antaryama, 2009).

Salah satu pantai di kabupaten Malang adalah pantai Sendang Biru. Pantai Sendang Biru memiliki potensi sumber daya perikanan yang besar di jawa Timur. Daya tarik berupa tempat pelelangan ikan dan pulau Sempu yang berada di sebrang pantai. Pulau Sempu ditetapkan sebagai cagar alam melalui Surat Keputusan Gubernur Jenderal Hindia Belanda (Besluit van den Gouverneur Generaal van Nederlandsch Indie) Nomor 46 Stbl No. 69 Tanggal 15 Maret 1928. Penetapan pulau seluas 877 Ha berdasarkan pada faktor botanis, estetis dan topografi (geologis) dengan potensi flora, fauna dan letaknya yang dekat dengan pulau Jawa memberikan nilai lebih terkait dengan keterwakilan kondisi hutan dan ekosistem daratan Pulau Jawa (Irawanto, 2017). Menurut UU No.5 tahun 1990 tentang Konservasi Sumber Daya Alam Hayati dan Ekosistemnya, penetapan kawasan hutan sebagai cagar alam karena kondisi alam, flora dan fauna yang khas memerlukan perlindungan bagi kepentingan ilmu pengetahuan dan kebudayaan.

Masyarakat di sekitar pantai Sendang Biru meyakini bahwa keberadaan pula Sempu adalah berkah. Kerusakan pada pulau Sempu akan membawa kerusakan pada kehidupan masyarakat seperti yang diungkapkan Saptoyo, salah satu warga, bahwa pesan nenek moyang terdahulu mulai terbukti (Miski, 2017) moral."

“Ketika Sempu rusak, maka akan merusak kehidupan masyarakat sekitar, baik secara fisik maupun

\section{Permasalahan}

Permasalahan saat ini yang terdapat pada pulau Sempu adalah adanya wisata illegal sehingga membuat sebagian wilayahnya menjadi rusak. Banyak masyarakat yang tidak peduli pada kondisi alam pulau Sempu. Sebagian kawasan di pulau Sempu akan diubah menjadi Taman Wisata Alam (TWA). TWA dapat berpotensi merusak kawasan cagar alam karena wisatawan pasti mempengaruhi kondisi alam. Menurut data Aliansi Peduli Cagar Alam Sempu (Istiawan, 2017), wisatawan yang secara illegal 
berkunjung ke pulau Sempu meninggalkan banyak sampah. Sampah di pulau Sempu tidak dapat diangkut keluar kecuali dengan perahu. Penurunan status cagar alam menjadi taman wisata alam mengundang para investor untuk dapat mengolah pulau Sempu menjadi destinasi wisata.

\section{Tujuan Penulisan/Pembahasan}

Tujuan penulisan kajian ini adalah untuk mengetahui strategi pengembangan pantai Sendang Biru untuk melestarikan pulau Sempu dan mempertahankan statusnya sebagai cagar alam.

\section{Metode Penelitian}

Kajian ini merupakan kajian deskriptif dengan sumber bahan berupa pustaka, literature atau penelitian terdahulu terkait dengan pantai Sendang Biru dan Pulau Sempu. Data tersebut digunakan untuk mengidentifikasi kearifan lokal pantai Sendang Biru dan Pulau Sempu. Indentifikasi kearifan lokal kemudian dianalisa sehingga mendapatkan strategi pengembangan pantai Sendang Biru untuk melestarikan pulau Sempu.

\section{Pantai Sendang Biru}

Pantai Sendang Biru merupakan salah satu pantai yang berada di kabupaten Malang. Pantai Sendang Biru terletak di desa Tambak Rejo, kecamatan Sumber Manjing Wetan pada 08 $37^{`}-08^{\circ} 41^{`}$ LS dan $112^{\circ} 35^{\prime}-112^{\circ} 43^{`}$ BT dengan ketinggian 0-100 m di atas permukaan laut. Batas admnistrasi pantai Sendang Biru adalah:

- Sebelah utara: desa Kendung Banteng

- Sebelah timur: desa Tambak Asri

- Sebelah selatan: samudra Indonesia

- Sebelah Barat: desa Sitiarjo

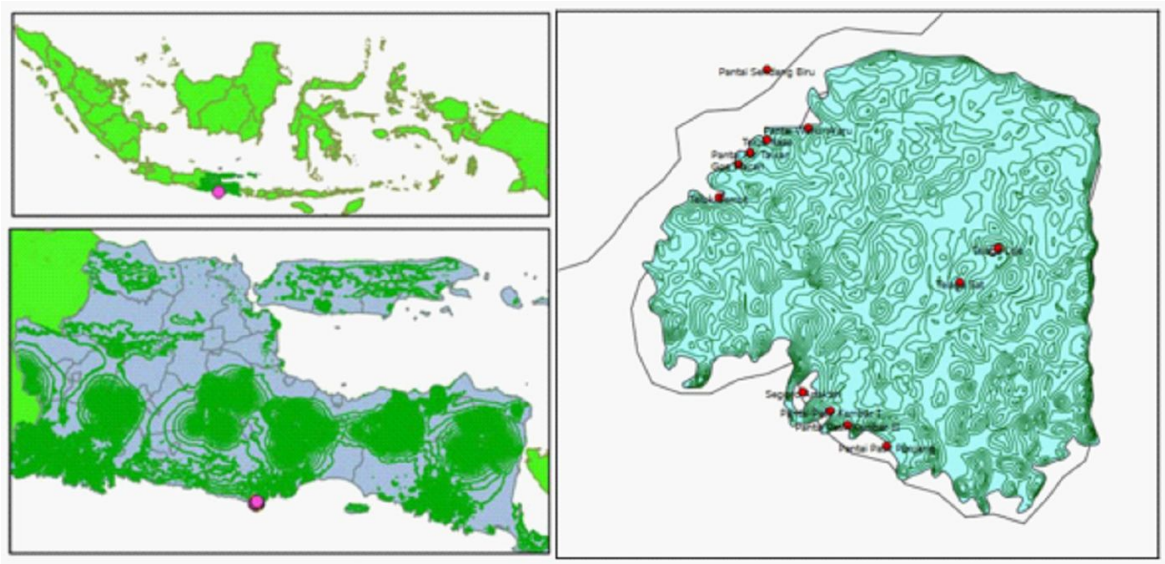

Gambar 1. Letak lokasi Pantai Sendang Biru dan Pulau Sempu. Sumber:(Irawanto, 2017) 
Pantai Sendang Biru merupakan pantai laut selatan yang curam dan berkarang dengan gelombang sedang hingga besar, arus pasang yang kuat yang terjadi dua kali sehari. Topografi wilayah Sendang Biru bebukit-bukit dengan lereng sedang hingga curam. Berada di ketinggian 50-250 meter di atas permukaan air laut, memiliki kemiringan lereng datar (<3\%), agak landai (3-8\%), agak curam (25$40 \%$ ) dan sangat curam (40\%). Pantai Sendang Biru terdiri dari beberapa bagian, bagian pantai dengn batuan kapur, karang dan berdinding terjal; sebagian yang lain merupakan pantai landai dengan panjang 50-100 m pada sisi timur dan barat. Tanah di wilayah Sendang Biru adalah batu kapur yang tidak subur dan mudah tererosi. Sehingga potensi perikananlah yang paling menonjol sebagai mata pencaharian masyarakat sekitar dengan hasil andalan tuna dan cakalang.

\section{Masyarakat Pantai Sendang Biru}

Manusia dan alam memiliki hubungan yang erat yang terlihat dari aktifitas-aktifitas yang dilakukan manusia untuk berinteraksi dengan kondisi iklim setempat. Interaksi ini dilakukan untuk memenuhi kebutuhan dan kenyamanan. Masyarakat Sendang Biru sebagian besar menggantungkan hidupnya dari hasil laut yang berlimpah.

\section{Matapencaharian nelayan}

Kawasan pantai Sendang Biru memiliki selat dengan barrier pulau Sempu. Keamanan para nelayan yang menangkap ikan lebih terjamin karena tidak berhadapann langsung dengan Samudra Hindia. Perairan Samudra Hindia sangatt kaya akan sumber daya ikan pelagis besar seperti madidihang(Thunnus albacares), tuna mata besar (Thunnus obesus), albakora (Thunnus allalunga), tuna sirip biru selatan (Thunnus macoyii), dan tuna abu-abu (Thunnus tonggol) dan cakalang (Katsuwonus pelamis) (Hermawan, 2006). Komisi Nasional pengkajian Stok Sumber Daya ikan Laut melakukan pengkajian pada tahun 1998. Dilaporkan bahwa sumber daya ikan tuna di wilayah selatan pulau Jawa sebesar 22.000 ton/tahun dengan tingkat produksi 10.000 ton/tahun. Hal tersebut memperlihatkan bahwa tingkat pemanfaatan baru $45 \%$ dan pengembangan masih terbuka sebesar $55 \%$.

Pantai Sendang Biru berdasarkan geografis, topografis, dan oceanografis adalah pantai terbaik kedua di selatan Jawa setelah Cilacap (Hermawan, 2006). Potensi pelabuhan ikan di Pantai Sendang Biru yaitu Pusat Pendaratan Ikan Pondokdadap adalah:

1. Berada di tepi Samudra Hindia yang merupakan wilayah Peengelolaan perikanan IX, dan sebagai alur migrasi terbesar ikan pelagis besar terutama ikan tuna

2. Pulau Sempu sebagai barrier, dengan panjang selat $4 \mathrm{~km}$, lebar 400-1500 m. Hal ini menyebabkan perairan yang relatif tenang,

3. Terjangkau oleh transportasi,

4. Kedalaman rataan $20 \mathrm{~m}$, cocok untuk berlabuhnya armada penangkapan baik dari nelayan Sendang Biru maupun dari luar daerah. 


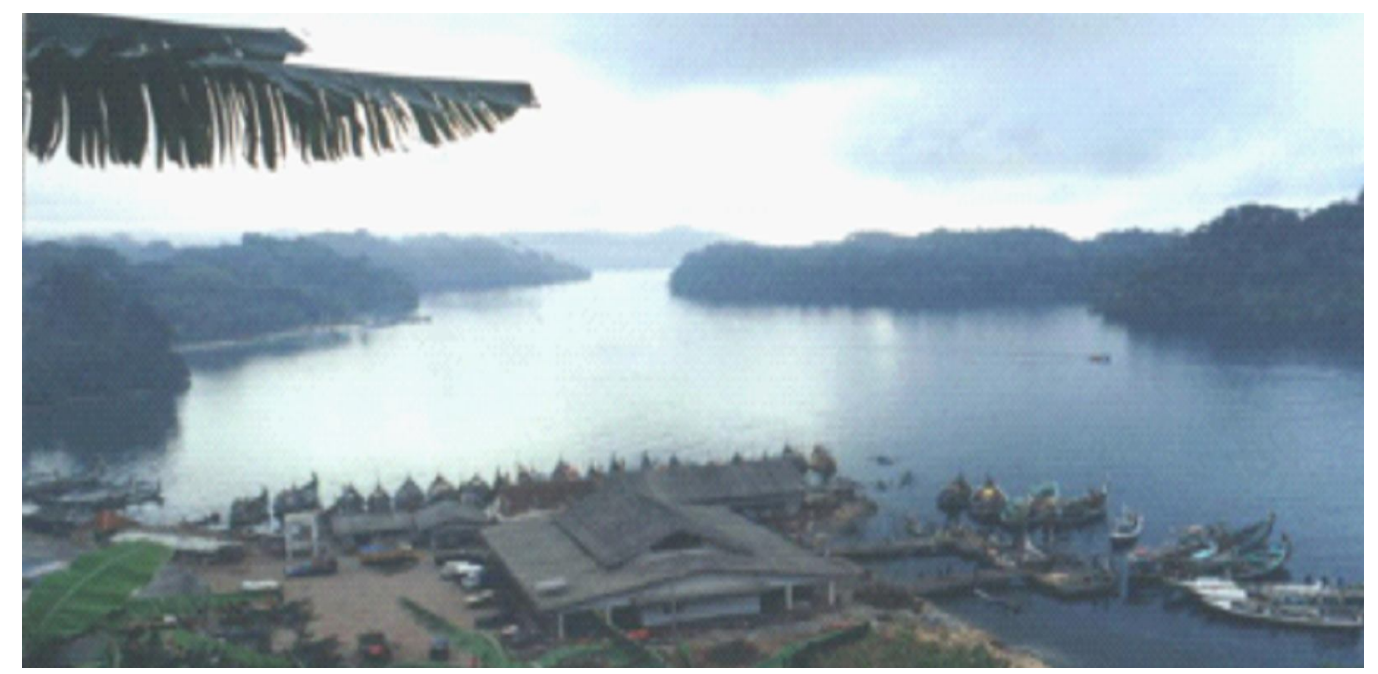

Gambar 2. Letak lokasi

Pantai Sendang Biru dan Pulau Sempu.

Sumber: (Hermawan, 2006)

Secara geografis daerah Sendang Biru terbagi atas daerah perbukitan dan pantai yang membagi penduduknya menjadi:

1. Nelayan atas, berasal dari etnik Jawa, beragama Kristen karena adanya pengaruh Belanda. Nelayan atas ini memiliki dua pekerjaan, yaitu sebagai nelayan dan petani ladang karena tempat tinggalnya yang berada di daerah bukit.

2. Nelayan bawah, nelayan yang hidup di kawasan pantai dan berasal dari etnik Madura. Beragama Islam dan menekuni pekerjaan sebagai nelayan.

3. Nelayan andong, adalah nelayan pendatang dari Cilacap, Bugis, Banyuwangi dan Kalimantan. Nelayan Andong menetap di Sendang Biru dengan mengontrak rumah selama musim melaut.

Berdasarkan perekonomiannya, kelompok nelayan dibedakan menjadi Nelayan "tidak" beruntung atau buruh nelayan (ABK), Kelompok nelayan yang memiliki kapal dan ABK, Kelompok bukan nelayan yang memiliki kapal dan ABK yang sering disebut juragan.

Masyarakat Sendang Biru mengenal Jaringan sosial rumah tangga nelayan-buruh atau disebut dengan pandhiga. Jaringan sosial ini memperlihatkan, mengembangkann dan memeilhara hubungan sosial berdasarkan kekerabatan. Dikenal pula hubungan patron-klien yang disebut pengambek, yaitu hubungan timbal balik antara pemilik modal dan ABK. Juragan atau pemilik modal memberikan perlindungan berupa pinjaman kepada ABK yang nantinya akan dikurangi setelah pembagian bagi hasil tangkapan ikan saat melaut dikurangi dengan biaya kehidupan di kapal saat melaut. Hubungan ini dapat menimbulkan aspek negatif dan terjadi karena pemilik modal menguasai sumber daya yang tidak dimiliki oleh ABK dan adanya hubungan kekerabatan sesama etnik. 
Adanya pengelompokan nelayan ini menyebabkan kondisi perekonomian nelayan ABK mendapatkan hasil yang tidak pasti dari pekerjaannya, sehingga mereka merubah matapencahariannya sebagai pengantar wisatawan untuk mengelilingi bahkan memasuki pulau Sempu yang terlarang.

\section{Ritual petik laut}

"Petik laut" berasal dari kata petik (bahasa jawa) yang berarti "ambil pungut" dan laut. Secara harafiah berarti memetik hasil usaha dari laut atau memetik hasil kelestarian kehidupan dari laut (Martin, 2011).

Ritual petik laut merupakan tradisi budaya masyarakat Sendang Biru. Setiap kebudayaan manusia memiliki beberapa unsur seperti religi, mata pencaharian, pengetahuan, organisasi dan teknologi (Martin, 2011). Sesuai dengan matapencaharian masyarakat Sendang Biru sebagai nelayan, ritual ini dimaksudkan sebagai upacara syukuran atas hasil panen laut yang diberikan oleh Sang Pencipta.

Ritual petik laut dilaksanakan setiap tanggal 27 September oleh masyarakat Sendang Biru. Ritual ini sarat akan berbagai pernak-pernik perelatan karena berasal dari masyarakat yang berbeda latar belakang budayanya. Pelaksanaan ritual petik laut memiliki serangkaian acara, antara lain:

1. Menjelang malam 27 September diadakan tasyakuran di itempat pelelangan pelabuhan perikanan Sendang Biru,

2. Keesokan paginya mempersiapkan perahu gitik dan sesaji yang akan dikirap atau dengan istilah ider bumi. Sesaji yang dikirap berupa gunungan tumpeng besar berwarna kuning, dilengkapi dengan sepasang temanten (boneka sepasang pengantin). Sesaji dikirap ke perkampungan nelayan dan berakhir di pelabuhan Sendang Biru.

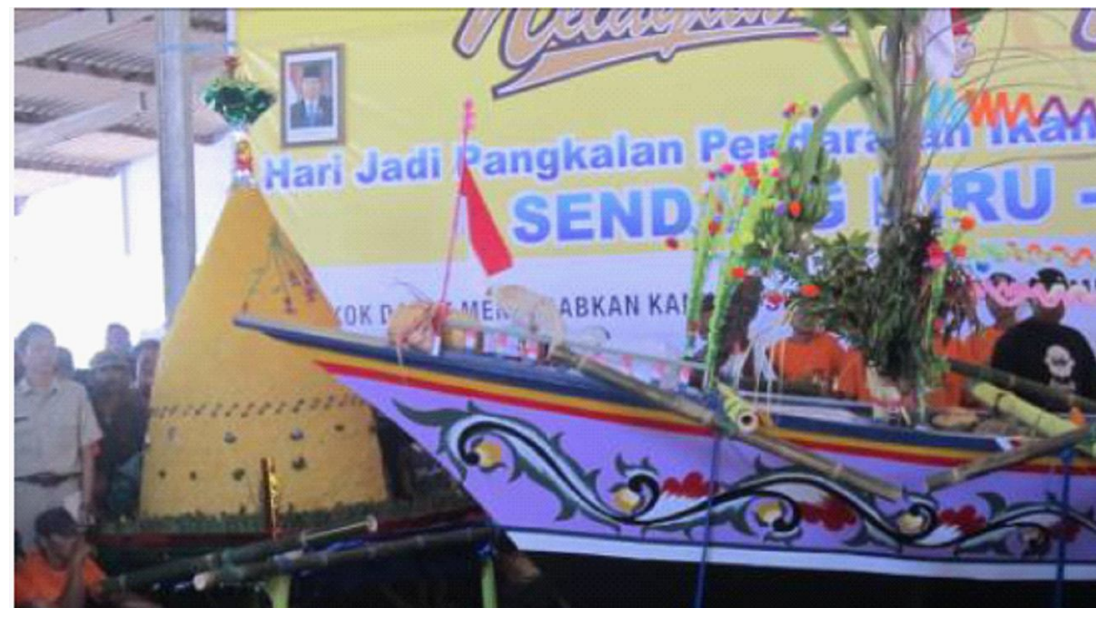

Gambar 3. Gunungan sesaji ritual petik laut Sumber: (Martin, 2011)

3. Pelarungan perahu gitik dengan gunungan dan simbol temanten diawali dengan memotong tali perahu yang tertambah di pelabuhan. Sesaji yang sudah dilarung diperebutkan para nelayan yang berada di tengah laut. 


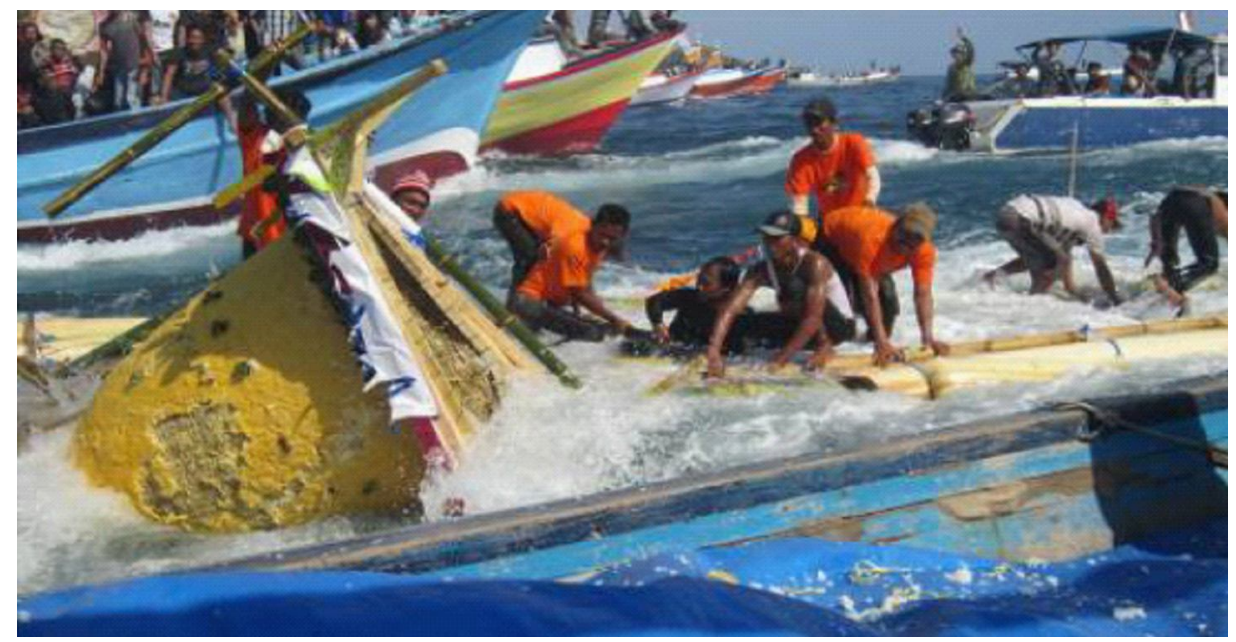

Gambar 4. Prosesi larung sesaji dalam ritual petik laut Sumber: (Martin, 2011)

4. Pada malam harinya diadakan pagelaran wayang kulit semalam suntuk sebagai penutup ritual petik laut.

Ritual petik laut memiliki makna mendalam tentang hubungan masyarakat Sendang Biru dengan sistem kearifan lokal yang dimilikinya. Kearifan lokal yang dimiliki masyarakat Sendang Biru adalah pengelolaan sumber daya alam termasuk sumber daya kelautan/ikan, pesisir dan hutan sebagai hubungan timbal balik manusia dengan alam sekitarnya.

\section{Pulau Sempu}

Pulau Sempu terletak di sebelah selatan pantai Sendang Biru. Terbentang 3,9 km dari barat ke timur dan 3,6 km dari utara ke selatan. Pulau Sempu berbatasan langsung dengan Samudra Indonesia di sebelah selatan dan timur, sedangkan pada bagian utara hingga barat berbatasan dengan selat Sempu yang memimsahkannya dengan Pulau Jawa. Pulau Sempu adalah pulau tidak berpenduduk dan memiliki keanekaragaman tumbuhan yang cukup beragam. Keanekaragaman tumbuhan pada pulau Sempu terdiri dari tumbuhan tingkat pohon sejumlah 296 jenis, tumbuhan tingkat tiang sejumlah 214 jenis, tumbuhan tingkat semak 103 jenis, dan tumbuhan bawah 126 jenis. Keanekaragaman satwa di pulau Sempu terdiri atas aves 47 jenis, mamalia 16 jenis, amfibi 4 jenis dan reptile 5 jenis. Selain jenis tumbuhan dan satwa yang tersebut diatas diperkirakan masih banyak spesies yang belum teridentifikasi menurut BBKSDA Jatim 2009 (Irawanto, 2017).

Topografi pulau Sempu berupa kontur yang bergelombang dan berbukit-bukit. Memiliki medan dengan lereng sedang (0-8\%) hingga curam (>45\%). Berada pada ketinggian 0-102 $\mathrm{m}$ di atas permukaan laut, memiliki jenis tanah litosol dan mediteran merah kecoklatan. Secara fisik jenis tanah tersebut dapat dilihat sebagai lapipsan humus yang tipis pada bagian pantai yang curam di wilayah selatan. 
Pulau Sempu yang ditetapkan sebagai cagar alam merupakan kawasan yang tepat untuk penelitian vegetasi. Pulau Sempu memiliki batas ekologi dengan empat tipe ekosistem yang memiliki ciri khas berbeda namun masih dalam satu kesatuan. Ekosistem-ekosistem yang terdapat pada Pulau Sempu adalah ekosistem hutan tropis dataran rendah pada sebagian besar daratan pulau, ekosistem hutan mangrove di beberapa pantai bagian utara, ekosistem danau, dan ekosistem hutan pantai dengan hamparn pasir putih pada sepanjang pantai utara ke arah barat.

Pulau Sempu juga memiliki sumber air tawar meskipun dikelilingi oleh selat dan samudra. Beberapa sumber air tawar tesebut adalah Telaga Lele seluas 1 ha yang dihuni banyak ikan lele, telaga Sat seluas 1,5 ha dan hanya berair pada musim hujan, dan Air tawar yang tertutup air pasang laut. Terdapat pula Laguna Segara Anakan berisi air pasang laut dari Samudra Hindia. Keindahan laguna terkesan utuh dan alami ini yang mengundang wisatawan sebagaii daya tarik tersendiri. Namun kunjungan wisatawan yang seraca illegal dapat merusak sebagian wilayah pulau Sempu. Kerusakan terdapat pada jalan setapak yang dilalui wisatawan serta tercemarnya pasir putih dengan tumpukan sampah yang tersebar di wilayah pantai.

\section{Pembahasan}

Analisis terhadap kearifan lokal terkait dengan sistem budaya masyarakat Sendang Biru sebagai nelayan dengan menggunakan variable religi dan pandangan hidup, mata pencaharian, organisasi masyarakat serta pengetahuan dan teknologi. Religi dan pandangan hidup terlihat dari ritual petik laut dengan pandangan hidup etnik Jawa dan Madura. Mata pencahariannya terkait pekerjaan sebagai nelayan yang mendorong perekonomian lokal. Organisasi masyarakat dengan adanya organisasi nelayan (HNI) dan organisasi antar kelompok pemilik kapal dengan ABK yang berasal dari etnik yang sama dengan sistem kekerabatan, dan KUD Mina. Untuk pengetahuan masyarakatSedang Biru muncul pada ketrampilan dalam melaut seperti mengemudikan kapal, pengetahuan tentang alat tangkap ikan, pengetahuan sumber daya ikan, teknologi perkapalan dan cuaca.

Dengan melihat kearifan lokal yang terdapat pada pantai Sendang Biru maka rekomendasi strategi pengembangan wisata dengan menjual potensi perikanan Sendang Biru. Wisata yang paling cocok adalah:

1. wisata kuliner dengan membangun tempat-tempat makan di sepanjang pantai dengan peneduhpeneduh alami.

2. Menjadikan ritual petik laut sebagai daya tarik dalam kalender wisata kabupaten Malang,

3. Menjadikan kehidupan nelayan dalam mencari ikan/melaut sebagai atraksi wisata untuk memperkenalkan kehidupan masyarakat lokal dalam menghargai alam

4. Mengajak serta masyarakat dalam pelestarian Pulau Sempu dengan menambah pemahaman pentingnya kelestarian Pulau Sempu.

5. Wisata alam Pulauu Sempu namun dengan pengawasan dan waktu yang terbatas 
Dengan adanya pengembangan wisata di Pantai Sendang Biru diharapkan dapat menarik wisata dan tetap melestarikan Pulau Sempu.

\section{Kesimpulan}

Pulau Sempu sebagai cagar budaya dapat dilestarikan dengan pengembangan wisata pantai Sendang Biru yang memperhatikan kearifan dan potensi lokal. Sehingga menjadi daya tarik tersendiri untuk berwisata hanya di pantai Sendang Biru. Dengan demikian kelestarian dan status cagar alam Pulau Sempu dapat dipertahankan.

\section{Referensi (Trebuchet 10 Bold)}

Antaryama, I. G. N. (2009). Bahasa Alam, Manusia dan Arsitektur di Darah Tropis Lembab/ : Sebuah Rujukan Arsitektur di Indonesia. Kearifan Lokal, 1, 20.

Hermawan, D. (2006). Prospektif Pengembangan Kawasan Pesisir Sendang Biru Untuk Industri Perikanan Terpadu, 13(2).

Irawanto, R. (2017). Kajian pustaka keanekaragaman tumbuhan di Cagar Alam Pulau Sempu, Jawa Timur, 3(Irawanto 2011), 138-146. https://doi.org/10.13057/psnmbi/m030123

Istiawan, H. (2017, September). Pulau Sempu, Antara Konservasi dan Komersialisasi. Okezone News.

Martin, R. (2011). Ritual Petik Laut pada Masyarakat Nelayan Sendang Biru, Malang/ : Sebuah Telaah Budaya Bahari. In International Conference ICSSIS (hal. 340-351). Jakarta.

Miski. (2017, September 2). Selamatkan Pulau Sempu! Warga yakini Kerusakan Pulau Sempu Akan Rusak Kehidupan Masyarakat. MalangVoice. 